Jurnal Ecobisma Vol 1 No. 12014

\title{
PENGARUH SISTEM INFORMASI SUMBER DAYA MANUSIA TERHADAP PERENCANAAN KARIR KARYAWAN PADA PT.PERKEBUNAN NUSANTARA III KEBUN AEK NABARA SELATAN
}

\author{
Yuniman Zebua \\ Dosen Sekolah Tinggi Ilmu Ekonomi (STIE) Labuhan Batu
}

\begin{abstract}
ABSTRAK
Tujuan penelitian ini adalah untuk mengetahui pengaruh sistem informasi sumber daya manusia terhaadap perencanaan karir karyawan pada PT. Perkebunan Nusantara III kebun Aek Nabara Selatan. Peneliti menarik hipotesis yaitu sistem informasi sumber daya manusia mempunyai pengaruh yang positif dan signifikan terhadap perencanaan karir karyawan pada PT. Perkebunan Nusantara III Kebun Aek Nabara Selatan.

Dalam penelitian ini diambil 138 sampel dari jumlah karyawan pada PT. Perkebunan Nusantara III Kebun Aek Nabara Selatan. Adapun variabel dalam penelitian meliputi 2 variabel yaitu Sistem Informasi Sumber Daya Manusia sebagai variabel X, dan Perencanaan Karir Karyawan sebagai variabel Y. Pengujian hipotesis menggunakan uji t dan koefisien regresi, dengan tingkat signifikan 5\%. Penganalisaan dat mengunakan software pengolahan data statistik yaitu SPSS versi 18.00 for windows. Teknik analisa data pada penelitian ini adalah statistic deskriptif, analisis regresi linier sederhana, uji validitas dan uji reliabilitas

Berdasarkan hasil analisis uji t variabel independent adalah sistem informasi sumber daya manusia (X) sebesar 31.330 $\geq \mathrm{t}_{\text {tabel }}$ sebesar 1.977 ini berarti $\mathrm{H}_{0}$ ditolak dan $\mathrm{H}_{1}$ diterima atau dengan kata lain sistem informasi sumber daya manusia berpengaruh secara signifikan terhadap perencanaan karir karyawan. Dari hasil koefisin determinan $\left(\mathrm{R}^{2}\right)$ didapat nilai sebesar 0.873.nilai sebesar 0.873ini menunjukkan bahwa perencanaan karir karyawan (Y) dapat menjelaskan sistem informasi sumber daya manusia (X) secara bersama - sama sebesar $87.3 \%$ dan sisanya $12.7 \%$ dipengaruhi oleh faktor lain diuar variabel independent.
\end{abstract}

Kata Kunci : Sistem Informasi Sumber Daya Manusia dan Perencanaan Karir Karyawan.

\section{PENDAHULUAN}

Di era globalisasi sekarang ini, perkembangan ilmu pengetahuan dan teknologi tumbuh dengan sangat baik. Sumber-sumber informasi mengenai ilmu pengetahuan dan teknologi sangatlah cepat dan akurat dalam mendapatkannya. Indonesia merupakan negara kepulauan yang memiliki banyak sumber daya alam dan sumber daya manusia yang sangat membutuhkan ilmu 


\section{Jurnal Ecobisma Vol 1 No. 12014}

pengetahuan dan teknologi untuk menunjang pembangunan perusahaan secara merata. Ilmu pengetahuan dan teknologi untuk pembangunan sebuah organisasi adalah sistem informasi.

Sebuah sistem informasi manajemen merupakan sebuah sistem informasi yang selain melakukan semua pengolahan transaksi yang perlu untuk sebuah organisassi, juaga member dukungan informasi dan pengolahan untuk fungsi manajemen dan pengambilan keputusan.

Sistem informasi juga sangat berpengaruh kepada pemimpin karena pimpinan dihadapkan kepada perubahan-perubahan tertentu. Sistem informasi manajemen mencakup semuan sistem manajemen yang ada di di perusahaan, termasuk manajemen sumber daya manusia. Sistem informasi sumber daya manusia (human resources information system) merupakan bentuk interseksi atau pertemuan antara bidang ilmu manajemen sumber daya manusia (MSDM) dan teknologi informasi. Sistem ini menggabungkan manajemen sumber daya manusia sebagai suatu displin yang utamanya mengaplikasikan bidang teknologi informasi ke dalam aktivitas - aktivitas manajemen sumber daya manusia seperti dalam hal perencanaan, dan menyusun sistem pemrosesan data dalam serangkaian langkah - langkah yang terstandarisasi dan terangkum dalam aplikasi perencanaan sumber daya perusahaan atau Enter Resource Planning (ERP). Salah satu alasan mereka adalah kuranyan pengetahuan mereka mengenai pembangunan dan pengembangan sistem ini. Oleh karena itu, pembanguan dan pengembang sistem informasi sumber daya manusia sangat penting.

Salah satu upaya dalam mendorong kemajuan para karyawan adalah dengan memberikan kesempatan kepada karyawan untuk merencanakan karir. Dimana suatu perencanaan karir ditandai dengan adanya kebutuhan, nilai, kemampuan, dan minat seseorang terhadap kebutuhan karir dan harus dapat menyesuaikan kebutuhan karir seseorang dan kesempatan karir yang ada. Perencanaan karir diperlukan oleh setiap karyawan untuk selalu siap meggunakan kesempatan karir yang ada sebaik-baiknya. PT. Perkebunan Nusantara III Kebun Aek nabara selatan harus ikut serta dalam perencanaan karir, guna menentukan tujuan dan jadwal bagi kemajuan karyawannya. Perusahaan harus mempertimbangkan minat, cita-cita, karir individu, ,memberikan nasehat tentang kesempatan untuk maju dalam perusahaan dan memberikan kegiatan pengembangkan yang diperlukan untuk mencapai tujuan yang telah disepakati bersama.

Perencanaan karir tidak hanya menguntungkan bagi karyawan secara personal tetapi menguntungkan juga bagi PT. Perkebunan Nusantara III Kebun Aek nabara selatan. Dengan 


\section{Jurnal Ecobisma Vol 1 No. 12014}

perencanaan karir memungkinkan perusahaan mengembangkan dan menempatkan karyawan dalam jabatan yang sesuai dengan minat, kebutuhan, dan tujuan karir.

Berdasarkan uraian tersebut, maka penulis tetarik untuk mengambil judul penelitian sebaga berikut: “ Pengaruh Sistem Sumber Daya Manusia Terhadap Perencanaan Karir Karyawan PT. Perkebunan Nusantara III Kebun Aek Nabara Selatan”.

\section{PERUMUSAN MASALAH}

Berdasarkan latar belakang masalah, maka penulis merumuskan masalah yaitu "Bagaimana pengaruh sistem informasi sumber daya manusia terhadap perencanaan karir karyawan pada PT. Perkebunan Nusantara III Kebun Aek Nabara Selatan?”

\section{TUJUAN PENELITIAN}

Adapun tujuan penelitian yang dilakukan penulis yaitu "Untuk mengetahui pengaruh sistem informasi sumber daya manusia terhadap perencanaan karir karyawan pada PT. Perkebunan Nusantara III Kebun Aek Nabara Selatan”.

\section{GAMBARAN TEORI}

\section{IV.1. Pengertian Sistem Informasi Sumber Daya Manusia}

Menurut T. Hani Handoko dalam buku manajemen personalia dan sumber daya manusia (2014: 237) sistem informasi sumber daya manusia adalah suatu prosedur sistematik pengumpulan, pemeliharaaan, perolehan kembali dan validasi berbagai data tertentu yang dibutuhkan oleh suatu organisasi tentang sumber daya manusianya, kegiatan-kegiatan personalia dan karakteristik-karakteristik satuan kerja.

Menurut H. M. Yani (2012: 173) sistem informasi sumber daya manusia merupakan serangkaian proses yang mencakup pada pengumpulan bahan, peringkasan, dan penganalisaan data berhubungan erat dengan manajemen sumber dya manusia dan perencanaan SDM.

Menurut Henry Simamora (2004: 90) sistem informasi sumber daya manusia adalah suatu proseduk sistematik mengumpulkan, menyimpan, mempertahankan, menarik, dan memvalidasi data yang dibutuhkan oleh sebuah organisasi tentang sumber daya manusia, aktivitas-aktivitas personalia, dan karakteristik-karakteristik unit organisasinya.

\section{IV.2. Model Sistem Informasi Sumber Daya Manusia}

Menurut H. M. Yani (2012: 175) model sistem informasi sumber daya meliputi : 


\section{Jurnal Ecobisma Vol 1 No. 12014}

\section{Subsistem Input}

a. SIA (sistem informasi akuntansi)

Sistem ini menyediakan data personil yang berkaitan dengan keuangan

b. Penelitian sumber daya manusia

Berfungsi untuk mengumpulkan data yang memiliki proyek penelitian khusus

c. Intelegen sumber daya manusia

Berfungsi mengumpulkan data berhubungan dengan sumber daya manusia dari lingkungan perusahaan yang meliputi :

1. Intelegen pemerintahan, pemerintah menyediakan data dan informasi yang membantu perusahaan mengikuti berbagai peraturan ketenagakerjaan.

2. Intelegen pemasok, pemasok mencakup perusahaan seperti perusahaan asuransi, yang memberikan imbalan kerja (employee benefit), dan lembaga penempatan lulusan universitas serta agen tenaga kerja, yang berfungsi sebagai sumber pegawai baru.

3. Intelegen serikat pekerja, serikat pekerja memberikan data dan informasi yang digunakan dalam mengatur kontrak kerja antara serikat pekerja dengan perusahaan.

4. Intelegen masyarakat global, masyarakat global menyediakan informasi yang menjelaskan sumber daya lokal, seperti perumahan, pendidikan, dan rekreasi.

5. Intelegen masyarakat keuangan, masyarakat keuangan memberikan data dan informasi ekonomi yang digunakan dalam perencanaan personil.

6. Intelegen pesaing, dalam industri tertentu yang memerlukan pengetahuan dan keahlian yang sangat khusus, seperti industri komputer, terjadi perpindahan pegawai yang sering dari satu perusahaan ke perusahaan lain.

2. Database Sumber Daya Manusia

Database yang digunakan adalah berbasis komputer yang meliputi :

a. Isi database

Data pegawai, seperti : tanggal lahir, nama, departemen, jabatan, tingkat pendidikan, dan lain - lain. Data non pegawai yang mengidentifikasi data dan menjelaskan organisasi di lingkungan perusahaan seperti agen tenaga kerja, akademis, universitas, serikat pekerja serta pemerintahan. 


\section{Jurnal Ecobisma Vol 1 No. 12014}

b. Lokasi database sistem informasi sumber daya manusia

Sebagai database sistem informasi sumber daya manusia ditempatkan pada komputer sentral perusahaan, tetapi database yang lain bisa berada di devisi khusus seperti pada devisi operasi lain dan luar pusat pelayanan.

c. Perangkat lunak manajemen database perangkat lunak yang digunakan dalam mengelola database sistem informasi sumber daya manusia perusahaan.

3. Subsistem output meliputi :

a. Subsistem perencanaan kerja.

Dalam subsistem ini meliputi kegiatan yang memungkinkan manajemen untuk mengidentifikasikan kebutuhan pegawai di masa yang akan datang. Adapun aplikasi dari perangkat lunak yang digunakan kebanyakkan seperti pembuatan bagan organisasi, peramalan gaji, analisis / evaluasi jabatan.

b. Subsistem perekrutan.

Dalam subsistem ini terdapat dua kegiatan / aplikasi yang biasa dilakukan, yaitu aplikasi pelacak pelamar dan aplikasi pencarian internal.

c. Subsistem manajemen angkatan kerja.

Subsistem angkatan kerja adalah sebuah output yang merupakan subsistem terbesar karena mnempunyai aplikasi yang cukup banyak namun sedikit sekali perusahaan yang menggunakannya.

\section{3. Pengertian Perencanaan Karir}

Menurut H. Edy Sutrisno (2012 : 179) perencanaan karir karyawan adalah suatu proses yang bertujuan agar karir tenaga kerja dapat dikembangkan sesuai dengan bakat dan kemampuannya sehingga bisa berfungsi dengan baik dan optimal bagi perusahaan.

Menurut T. Hani Handoko (2014 : 121) perencanaan karir adalah proses melalui mana seseorang memilih sasaran karir, dan jalur ke sasaran tersebut.

Menurut H. M. Yani (2012 : 107) perencanaan karir adalah proses dimana seseorang memilih tujuan karir dan urutan karir untuk mencapai tujuan tersebut.

Menurut Henry Simamora (2004: 504) perencanaan karir dalah pengembangan karir yang dilaksanakan untuk memenuhi kebutuhan tenaga kerja yang terampil dan cakap di mulai merekrut tenaga kerja, menyeleksi, menempatkan pengawai kemudian mengevaluasi hasil tenaga kerja. 


\section{Jurnal Ecobisma Vol 1 No. 12014}

Perencanaan karir merupakan suatu bagian yang sangat penting bagi karyawan dalam melaksanakan suatu pekerjaan untuk mencapai tujuan. Adapun konsep dasar perencanaan karir yaitu :

1. Karir sebagai suatu urutan promosi atau pemindahan (transfer) lateral ke jabatan jabatan yang lebih menuntutkan tanggung jawab atau ke lokasi - lokasi yang lebih baik dalam atau menyilang hirarki hubungan kerja selama kehidupan kerja seseorang

2. Karir sebagai penunjuk pekerjaaan - pekerjaan yang membentuk suatu pola kemajuan yang sistematik jelas jalur karir

3. Karir sebagai sejarah pekerjaan seseorang, atau serangkaian posisi yang dipegangnya selama kehidupan kerja

\section{IV.4. Ruang Lingkup Perencanaan Karir}

Perencanaan karir merupakan bagian yang sangat penting karena menentukan dinamika organisasi atau perusahaan untuk manajemen sumber daya manusia. Menurut H. Sadili Samsudin (2010: 134) ruang lingkup perencanaan karir mencakup hal - hal sebagai berikut :

1. Perencanaan jenjang jabatan atau pangkat karyawan Jabatan adalah kedudukan yang menunjukkan tugas, tanggung jawab, wewenang, dan hak seorang karyawan dalam suatu rangkai susunan organisasi. Pangkat adalah kedudukan tingkat seorang karyawan atau pegawai dalam rangkain susunan kepegawaian dan yang digunakan sebagai dasar penggajian. Suatu perencanaan jenjang jabatan / pangkat perlu memperhatikan faktor - faktor, yaitu sifat tugas, dan tanggung jawab. Secara khusus jenjang karir jabatan bertujuan untuk :

a. Memberikan kepastian arah karir jabatan karyawan dalam kiprahnya di lingkup organisasi

b. Meningkatkan daya tarik organisasi bagi karyawan yang berkualitas

c. Memudahkan manajemen dalam menyelenggarakan program-program pengembangan sumber daya manusia, khususnya dalam rangka mengambil keputusan dibidang karir serta perencanaan sumber daya manusia organisasi atau perusahaan yang selaras dengan rencana pengembangan organisasi

d. Memudahkan administrasi kepegawaian, khususnya dalam melakukan administrasi pergerakkan karyawan dalam arah karir promosi, rotasi, ataupun demosi jabatan

2. Perencanaan tujuan organisasi 


\section{Jurnal Ecobisma Vol 1 No. 12014}

Suatu organisasi atau perusahaan mutlak harus mempunyai tujuan yang jelas. Perumusan tujuan harus didasarkan pada perencanaan yang matang sebab dari tujuan organisasi dapat ditentukan :

a. Besar kecilnya misi organisasi atau perusahaan

b. Berat ringannya tugas pekerjaan

c. Spesifikasi pekerjaan yang perlu dirumuskan

d. Jenis kelompok pekerjaan yang disusun

e. Kuantitas dan kualitas personil yang diperlukan

Tujuan organisasi mulai dari tingkat teratas sampai dengan yang dibawah akan menentukan jalur karir anggota organisasi atau perusahaan.

\section{IV.5. Penyusunan Perencanaan karir}

Menurut H. Sadili Samsudin (2010: 135) dalam penyusunan perencanaan karir diperlukan 4 hal pokok yaitu :

1. Jabatan pokok atau jabatan penunjang

Jabatan pokok adalah jabatan yang fungsi dan tigas pokoknya menunjang langsung tercapainya sasaran pokok organisasi atau perusahaan. Jabatan penunjang adalah jabatan yang fungsi dan tugasnya menunjang atau membantu tercapainya sasaran pokok organisasi atau perusahaan

2. Pola jalur karir bertahap

Pola jalur karir bertahap adalah suatu pola yang menunjukkan urutan berjenjang dan bertahap dari jabatan-jabatan dalam struktur organisasi yang membentuk karir seseorang.

3. Jabatan struktural

Jabatan struktural adalah jabatan karir, artinya jabatan yang diperuntukkan bagi mereka yang di arahkan ke jenjang yang tinggi dalam organisasi.

4. Tenggang waktu

Tenggang waktu jabatan sesorang atau masa jabatan seseorang dalam suatu organisasi sebaiknya ditentukan secara tegas dan pasti sebab hal tersebut akan memberikan efek psikologis yang positif terhadap pemangku jabatan yang bersangkutan. 


\section{Jurnal Ecobisma Vol 1 No. 12014}

\section{METODE PENELITIAN}

Lokasi penelitian dilaksanakan pada PT. Perkebunan Nusantara III Kebun Aek Nabara Selatan, Kecamatan Bilah Hulu, Kabupaten Labuhanbatu Sumatera Utara.Variabel yang diteliti adalah Sistem Informasi Sumber Daya Manusia dan Perencanaan Karir Karyawan

\section{V.1. Instrumen Pengumpulan Data}

Instrumen pengumpulan data merupakan hal yang sangat penting dalam sebuah penelitian. Berhasil tidaknya sebuah penelitian tergantung oleh kemampuan penulis dalam menentukan instrumen pengumpulan data.

Adapun instrumen pengumpulan data yang digunakan peneliti yaitu skala likert.

Tabel V.1

Instrumen Skala Likert

\begin{tabular}{|l|l|l|}
\hline NO & Pertanyaan & Skor \\
\hline 1 & Sangat Setuju (SS) & 5 \\
\hline 2 & Setuju (S) & 4 \\
\hline 3 & Kurang Setuju (KS) & 3 \\
\hline 4 & Tidak Setuju (TS) & 2 \\
\hline 5 & Sangat Tidak Setuju (STS) & 1 \\
\hline
\end{tabular}

Sumber : Sugiono (2014:169)

\section{V.2. Teknik Analisa Data}

\section{Statistik deskriptif}

Statistik deskriptif adalah statistik yang digunakan untuk menganalisis data dengan cara mendeskripsikan atau menggambarkan data yang telah terkumpul sebagaimana adanya tanpa bermaksud membuat kesimpulan yang berlaku untuk umum. Dalam menentukan statistic deskriptif, peneliti menggunakan program SPSS versi 18.00 for windows.

\section{Analisa regresi linear sederhana}

Untuk mengetahui pengaruh-pengaruh variabel bebas terhadap variabel terikat digunakan analisis regresi linear sederhana dengan rumus:

$$
\mathrm{Y}=\mathrm{a}+\mathrm{bX}
$$

Dimana : 


\section{Jurnal Ecobisma Vol 1 No. 12014}

$\begin{array}{ll}\mathrm{Y} & : \text { Perencanaan Karir } \\ \mathrm{a} & : \text { Konstanta } \\ \mathrm{b} & : \text { Koefisien regresi } \\ \mathrm{X} & : \text { Sistem Informasi Sumber Daya Manusia }\end{array}$

Dalam menentukan analisa regresi linear sederhana, peneliti menggunakan program SPSS versi 18.00 for windows.

\section{Uji validitas dan reabilitas}

\section{a. Uji validitas}

Uji validitas merupakan tingkatan kevalidan atau kesahihan suatu instrumen. Instrumen dikatakan valid apabila mampu mengukur apa yang diinginkan dan dapat mengungkapkan data dari variabel yamg diteliti secara tepat.

Jika $\mathrm{r}_{\text {hitung }} \geq \mathrm{r}_{\text {tabel }}$ untuk taraf signifikasi $95 \%$ maka angket yang digunakan valid

Dalam menentukan uji validitas, peneliti menggunakan program SPSS versi 18.00 for windows.

\section{Tabel V.2}

\section{Pedoman Untuk Memberikan Interprestasi Koefisien Korelasi}

\begin{tabular}{|l|l|}
\hline $\begin{array}{l}\text { Interval } \\
\text { Koefisien }\end{array}$ & Tingkat Hubungan \\
\hline $0,00-0,199$ & Sangat Rendah \\
$0,20-0,399$ & Rendah \\
$0,40-0,599$ & Sedang \\
$0,60-0,799$ & Kuat \\
$0,80-1,000$ & Sangat kuat \\
\hline
\end{tabular}

Sumber : Sugiono (2014:287)

\section{b. Uji reabilitas}

Reabilitas menunjukkan pada suatu pengertian bahwa suatu instrumen cukup dapat dipercaya untuk digunakan sebagai alat pengumpulan data karena instrumen tersebut sudah baik. Instrumen yang baik merupakan instrumen yang dapat dipercaya. Untuk menghitung reabilitas digunakan alpha, dimana suatu instrumen dapat dikatakan reliabe bila memiliki koefisien keandalan atau alpha lebih besar dari $r_{\text {tabel. }}$. Dalam menentukan uji reabilitas, peneliti menggunakan program SPSS versi 18.00 for windows. 


\section{Jurnal Ecobisma Vol 1 No. 12014}

\section{Pengujian hipotesis}

\section{a. Uji parsial (Uji t)}

Pengujian ini menunjukkan pengaruh satu per satu variabebebas terhadap variabel terikat. Pengujian ini dilakukan dengan membandingkan antara nilai thitung dengan nilai tabel dengan kriteria keputusan adalah :

- Jika thitung $<$ tabel $\mathrm{H}_{0}$ diterima atau $\mathrm{H}_{1}$ ditolak

- Jika thitung > ttabel $\mathrm{H}_{0}$ ditolak atau $\mathrm{H}_{1}$ diterima

Atau membandingkan antara nilai sig dengan nilai alpha dengan kriteria keputusan adalah :

Apabila nilai sig lebih kecil dari nilai alpha maka $\mathrm{H}_{0}$ ditolak atau $\mathrm{H}_{1}$ diterima.

Apabila nilai sig lebih besar nilai alpha maka $\mathrm{H}_{0}$ diterima atau $\mathrm{H}_{1}$ ditolak.

Dalam menentukan uji parsial (Uji t), peneliti menggunakan program SPSS versi 18.00 for windows.

\section{b. Koefisien determinasi (R2)}

Koefisien determinasi (R2) pada intinya untuk mengukur proposi atau presentasi sumbangan variabel bebas yaitu pengaruh sistem informasi sumber daya manusia $(X)$ terhadap variabel perencanaan karir karyawan (Y) sebagai variabel terikat. Dalam menentukan koefisien determinasi (R2), peneliti menggunakan program SPSS versi 18.00 for windows.

\section{HASIL PENELITIAN DAN PEMBAHASAN}

PT. Perkebunan Nusantara III Kebun Aek Nabara Selatan berjarak lebih kurang 307 km dari kota Medan berlokasi di kecamatan Bilah Hulu Kabupaten Labuhanbatu yang melalui jalan lintas Sumatera-Jawa, sehingga letaknya sangat strategis dalam pengembangan industri hilir.

\section{1. Pembahasan}

\section{Analisis karakteristik responden}

a. Karakteristik Responden Berdasarkan Usia

Tabel VI.1

Karakteristik Usia Responden

\begin{tabular}{|l|l|c|c|}
\hline No & Usia & Jumlah (Orang) & Persentase (\%) \\
\hline 1 & $20-30$ Tahun & 39 & $28.1 \%$ \\
\hline 2 & $31-40$ Tahun & 50 & $36.1 \%$ \\
\hline 3 & $41-50$ Tahun & 43 & $31.1 \%$ \\
\hline 5 & $\geq 51$ tahun & 6 & $4.3 \%$ \\
\hline
\end{tabular}


Jurnal Ecobisma Vol 1 No. 12014

Jumlah

138

$100 \%$

Sumber : Data Diolah (2015)

Berdasarkan Tabel 4.1 mengenai karakteristik responden berdasarkan usia paling dominan dalam penelitian ini adalah usia 31-40 tahun sebanyak 50 orang atau 36.1\%, usia 20-30 tahun sebanyak 43 orang atau 31.1\%, usia 41-51 tahun sebanyak 39 orang atau 28.1\%, dan responden terkecil antara usia $\geq 51$ tahun sebanyak 6 orang atau $4.3 \%$.

\section{b. Karakteristik Responden Berdasarkan Jenis Kelamin}

\section{Tabel VI.2}

Karakteristik Jenis Kelamin Responden

\begin{tabular}{|l|l|c|c|}
\hline No & Jenis Kelamin & Jumlah (Orang) & Persentase (\%) \\
\hline 1 & Laki-laki & 133 & $96.4 \%$ \\
\hline 2 & Perempuan & 5 & $3.6 \%$ \\
\hline Jumlah & 138 & $100 \%$ \\
\hline
\end{tabular}

Sumber : Data Diolah (2015)

Berdasarkan Tabel 4.2 mengenai karakteristik responden berdasarkan jenis kelamin paling dominan dalam penelitian ini adalah laki-laki sebanyak 133 orang atau $96.4 \%$ dan responden terkecil adalah jenis kelamin perempuan sebanyak 5 orang atau 3.6\%.

c. Karakteristik Responden Berdasarkan Pendidikan Terakhir

Tabel VI.3

Karakteristik Pendidikan Terakhir Responden

\begin{tabular}{|l|l|c|c|}
\hline No & \multicolumn{1}{|c|}{$\begin{array}{c}\text { Pendidikan } \\
\text { Terakhir }\end{array}$} & Jumlah (Orang) & Persentase (\%) \\
\hline 1. & SD & 12 & $8.7 \%$ \\
\hline 2. & SMP & 29 & $21.0 \%$ \\
\hline 3. & SMA & 92 & $66.7 \%$ \\
\hline 4. & Sarjana & 5 & $3.6 \%$ \\
\hline \multicolumn{2}{|l|}{ Jumlah } & 138 & $100 \%$ \\
\hline
\end{tabular}

Sumber : Data Diolah (2015)

Berdasarkan Tabel 4.3 mengenai karakteristik responden berdasarkan pendidikan terakhir paling dominan dalam penelitian ini adalah SMA sebanyak 92 orang atau $66.7 \%$ dan responden 


\section{Jurnal Ecobisma Vol 1 No. 12014}

terkecil adalah pendidikan terakhir SMP sebanyak 29 orang atau $21.0 \%$, SD sebanyak 12 orang atau $8.7 \%$ dan sarjana sebanyak 5 orang atau $3.6 \%$.

\section{d. Karakteristik responden berdasarkan masa kerja}

Tabel VI.4

Karakteristik Masa Kerja Responden

\begin{tabular}{|l|l|l|l|}
\hline No & Masa kerja & $\begin{array}{l}\text { Jumlah } \\
(\text { Orang) }\end{array}$ & Persentase (\%) \\
\hline 1. & $1-5$ Tahun & 37 & $25.8 \%$ \\
\hline 2. & $5-10$ Tahun & 5 & $3.6 \%$ \\
\hline 3. & $11-15$ Tahun & 46 & $33.3 \%$ \\
\hline 4. & $16-20$ Tahun & 34 & $24.6 \%$ \\
\hline 5. & $\geq 21$ Tahun & 16 & $11.6 \%$ \\
\hline \multicolumn{2}{|c|}{ Jumlah } & 138 & $100 \%$ \\
\hline
\end{tabular}

Sumber : Data Diolah (2015)

Berdasarkan Tabel 4.1 mengenai karakteristik responden berdasarkan masa kerja paling dominan dalam penelitian ini adalah masa kerja 11--15 tahun sebanyak 46 orang atau 33.3\% dan responden terkecil adalah masa kerja 5-10 tahun sebanyak 5 orang atau 3.6\%.

\section{Statistik deskriptif}

a. Variabel sistem informasi sumber daya manusia $(\mathbf{X})$

Tabel VI.5

Sistem Informasi Sumber Daya Manusia

\begin{tabular}{|c|c|c|c|c|c|c|c|c|c|c|c|}
\hline \multirow{2}{*}{$\begin{array}{l}\text { No } \\
\text { item }\end{array}$} & \multicolumn{2}{|l|}{ SS } & \multicolumn{2}{|l|}{$S$} & \multicolumn{2}{|c|}{$\mathrm{KS}$} & \multicolumn{2}{|c|}{ TS } & \multicolumn{2}{|c|}{ STS } & \multirow[t]{2}{*}{ Total } \\
\hline & $F$ & $\%$ & $F$ & $\%$ & $F$ & $\%$ & $\mathrm{~F}$ & $\%$ & $F$ & $\%$ & \\
\hline 1 & 24 & $17.4 \%$ & 114 & $82.5 \%$ & 0 & $0 \%$ & 0 & $0 \%$ & 0 & $0 \%$ & $100 \%$ \\
\hline 2 & 41 & $29.6 \%$ & 91 & $65.9 \%$ & 6 & $2.3 \%$ & 0 & $0 \%$ & 0 & $0 \%$ & $100 \%$ \\
\hline 3 & 29 & $21.0 \%$ & 104 & $75.4 \%$ & 5 & $3.6 \%$ & 0 & $0 \%$ & 0 & $0 \%$ & $100 \%$ \\
\hline 4 & 23 & $16.7 \%$ & 115 & $83.3 \%$ & 0 & $0 \%$ & 0 & $0 \%$ & 0 & $0 \%$ & $100 \%$ \\
\hline 5 & 25 & $18.1 \%$ & 113 & $81.9 \%$ & 0 & $0 \%$ & 0 & $0 \%$ & 0 & $0 \%$ & $100 \%$ \\
\hline
\end{tabular}




\section{Jurnal Ecobisma Vol 1 No. 12014}

\begin{tabular}{|l|l|l|l|l|l|l|l|l|l|l|l|}
\hline 6 & 42 & $30.4 \%$ & 84 & $60.9 \%$ & 12 & $8.7 \%$ & 0 & $0 \%$ & 0 & $0 \%$ & $100 \%$ \\
\hline 7 & 61 & $44.2 \%$ & 54 & $39.1 \%$ & 23 & $16.7 \%$ & 0 & $0 \%$ & 0 & $0 \%$ & $100 \%$ \\
\hline 8 & 25 & $18.1 \%$ & 113 & $81.9 \%$ & 0 & $0 \%$ & 0 & $0 \%$ & 0 & $0 \%$ & $100 \%$ \\
\hline 9 & 27 & $19.6 \%$ & 108 & $78.3 \%$ & 3 & $2.2 \%$ & 0 & $0 \%$ & 0 & $0 \%$ & $100 \%$ \\
\hline 10 & 26 & $18.8 \%$ & 122 & $81.2 \%$ & 0 & $0 \%$ & 0 & $0 \%$ & 0 & $0 \%$ & $100 \%$ \\
\hline
\end{tabular}

\section{Sumber : Data Diolah (2015)}

Berdasarkan tabel 4.5 dappat dilihat bahwa :

1. Dari 138 responden, yang menyatakan setuju ada114 responden atau $82.5 \%$ dan yang menyatakan sangat setuju ada 24 responden atau $17.4 \%$

2. Dari 138 responden, yang menyatakan setuju ada 91 responden atau $65.9 \%$, yang menyatakan sangat setuju ada 41 responden atau $29.6 \%$ dan yang menyatakan kurang setuju ada 6 responden atau $2.3 \%$.

3. Dari 138 responden, yang menyatakan setuju ada104 responden atau $75.4 \%$, yang menyatakan sangat setuju ada 29 responden atau $21.0 \%$ dan yang menyatakan kurang setuju ada 5 responden atau $3.6 \%$.

4. Dari 138 responden, yang menyatakan setuju ada 115 respondeen atau $83.3 \%$ dan yang mneyatakan sangat setuju ada 23 responden atau $16.7 \%$.

5. Dari 138 responden yang menyatakan setuju ada 118 respondenn atau $81.9 \%$ dan yang menyatakan sangat setuju ada 25 responden atau $18.1 \%$.

6. Dari 138 responden, yang menyatakan setuju ada 84 respondeen atau $60.9 \%$, yang menyatakan sangat setuju ada 42 responden atau $30.4 \%$ dan yang menyatakan kurang setuju ada 12 responden atau $8.7 \%$.

7. Dari 138 responden, yang menyatakan setuju ada 61 responden atau $44.2 \%$, yang menyatakan sangat setuju ada 54 responden atau 39.1\%, yang menyatakan kurang setuju ada 23 responden atau $16.7 \%$.

8. Ddari 138 responden, yang menyatakan setuju ada 113 respondn atau $81.9 \%$ dan yang menyatakan sangat setuju ada 25 responden atau $44.2 \%$.

9. Dari 138 responden yang menyatakan setuju ada 108 responden atau $78.3 \%$, yang menyatkan sangat setuju ada 27 responden atau $19.6 \%$ dan yang menyatakan kurang setuju ada 3 responden atau $2.2 \%$. 


\section{Jurnal Ecobisma Vol 1 No. 12014}

10. Dari 138 responden yang menyatakan setuju ada 122 responden atau $81.2 \%$ dan yang menyatakan sangat setuju ada 26 responden atau $18.8 \%$.

\section{b. Variabel Perencanaan Karir Karyawan (Y)}

Tabel VI.6

Perencanaan karir

\begin{tabular}{|c|c|c|c|c|c|c|c|c|c|c|c|}
\hline \multirow{2}{*}{$\begin{array}{l}\text { No } \\
\text { item }\end{array}$} & \multicolumn{2}{|l|}{$\mathrm{SS}$} & \multicolumn{2}{|l|}{ S } & \multicolumn{2}{|c|}{$\mathrm{KS}$} & \multicolumn{2}{|c|}{$\mathrm{TS}$} & \multicolumn{2}{|c|}{ STS } & \multirow[t]{2}{*}{ Total } \\
\hline & $\mathrm{F}$ & $\%$ & $\mathrm{~F}$ & $\%$ & $\mathrm{~F}$ & $\%$ & $\mathrm{~F}$ & $\%$ & $\mathrm{~F}$ & $\%$ & \\
\hline 1 & 25 & $18.1 \%$ & 69 & $50.0 \%$ & 7 & $0.7 \%$ & 0 & $0 \%$ & 0 & $0 \%$ & $100 \%$ \\
\hline 2 & 16 & $11.6 \%$ & 119 & $86.2 \%$ & 3 & $2.2 \%$ & 0 & $0 \%$ & 0 & $0 \%$ & $100 \%$ \\
\hline 3 & 16 & $11.6 \%$ & 120 & $87.0 \%$ & 2 & $1.4 \%$ & 0 & $0 \%$ & 0 & $0 \%$ & $100 \%$ \\
\hline 4 & 23 & $16.7 \%$ & 104 & $75.4 \%$ & 11 & $8.0 \%$ & 0 & $0 \%$ & 0 & $0 \%$ & $100 \%$ \\
\hline 5 & 40 & $29.0 \%$ & 98 & $71.0 \%$ & 0 & $0 \%$ & 0 & $0 \%$ & 0 & $0 \%$ & $100 \%$ \\
\hline 6 & 6 & $4.3 \%$ & 124 & $89.9 \%$ & 8 & $5.8 \%$ & 0 & $0 \%$ & 0 & $0 \%$ & $100 \%$ \\
\hline 7 & 16 & $11.6 \%$ & 119 & $86.2 \%$ & 3 & $2.2 \%$ & 0 & $0 \%$ & 0 & $0 \%$ & $100 \%$ \\
\hline 8 & 15 & $10.9 \%$ & 97 & $70.3 \%$ & 26 & $18.8 \%$ & 0 & $0 \%$ & 0 & $0 \%$ & $100 \%$ \\
\hline 9 & 3 & $2.2 \%$ & 120 & $87.0 \%$ & 15 & $10.9 \%$ & 0 & $0 \%$ & 0 & $0 \%$ & $100 \%$ \\
\hline 10 & 70 & $50.7 \%$ & 68 & $49.3 \%$ & 0 & $0 \%$ & 0 & $0 \%$ & 0 & $0 \%$ & $100 \%$ \\
\hline
\end{tabular}

\section{Sumber : Data Diolah (2015)}

Berdasarkan tabel 4.6 dapat dilihat bahwa :

1. Dari 138 responden, yang menyatakan setuju ada 69 responden atau $50.0 \%$, yang menyatakan sangat setuju ada 25 responden atau $18.1 \%$ dan yang menyatakan kuarang setuju ada 7 responden atau $0.7 \%$.

2. Dari 138 responden, yang menyatakan setuju ada 119 responden atau 86.2\%, yang menyatakan sangat setuju ada 16 responden atau $11.6 \%$ dan yang menyatakan kurang setuju ada 3responden atau $2.2 \%$.

3. Dari 138 responden, yang menyatakan setuju ada120 responden atau $87.0 \%$, yang menyatakan sangat setuju ada 16 responden atau $11.6 \%$ dan yang menyatakan kurang setuju ada 2 responden atau $1.4 \%$.

4. Dari 138 responden, yang menyatakan setuju ada 115 respondeen atau $83.3 \%$ dan yang mneyatakan sangat setuju ada 23 responden atau $16.7 \%$. 


\section{Jurnal Ecobisma Vol 1 No. 12014}

5. Dari 138 responden yang menyatakan setuju ada 98 respondenn atau $71.0 \%$ dan yang menyatakan sangat setuju ada 40 responden atau $29.0 \%$.

6. Dari 138 responden, yang menyatakan setuju ada 124 respondeen atau $89.9 \%$, yang menyatakan sangat setuju ada 6 responden atau $4.3 \%$ dan yang menyatakan kurang setuju ada 8 responden atau $5.8 \%$.

7. Dari 138 responden, yang menyatakan setuju ada 119 responden atau 86.2\%, yang menyatakan sangat setuju ada 16 responden atau $11.6 \%$, yang menyatakan kurang setuju ada 3 responden atau $22 \%$.

8. Dari 138 responden, yang menyatakan setuju ada 97 responden atau $70.3 \%$, yang menyatakan sangat setuju ada 15 responden atau $10.9 \%$ dan yang menyatakan kurang setuju ada 26 responden atau $18.8 \%$.

9. Dari 138 respondenyang menyatakan setuju ada 120 responden atau $87.0 \%$, yang menyatkan sangat setuju ada 3 responden atau $2.2 \%$ dan yang menyatakan kurang setuju ada15 responden atau $109 \%$.

10. Dari 138 responden yang menyatakan sangat setuju ada70 responden atau $50.7 \%$ dan yang menyatakan setuju ada 68 responden atau $49.3 \%$.

\section{Analisis regresi linear sederhana}

Analisis regresi linear bertujuan untuk mengetahui pengaruh variabel independen (sistem informasi sumber daya manusia) terhadap variabel dependen (perencanaan karir karyawan), yaitu sebagai berikut :

Tabel VI.7

\section{Hasil perhitungan Regresi linier sederhana}

coefficients $^{\mathrm{a}}$

\begin{tabular}{|l|l|l|l|l|l|}
\hline Model & \multicolumn{2}{|l|}{$\begin{array}{l}\text { Unstandardized } \\
\text { Coefficints }\end{array}$} & $\begin{array}{l}\text { Standardized } \\
\text { Coefficies }\end{array}$ & $\mathrm{t}$ & Sig. \\
\cline { 2 - 6 } & B & Std. Error & Beta & \\
\hline $\begin{array}{l}\text { (constant) } \\
\begin{array}{l}\text { Sistem Informasi } \\
\text { Sumber Daya } \\
\text { Manusia }\end{array}\end{array}$ & .973 & 1.307 & & .928 & .355 \\
\hline
\end{tabular}

a. Dependent Variabel : Perencanaan Karir 


\section{Jurnal Ecobisma Vol 1 No. 12014}

$\mathrm{Y}=\mathrm{a}+\mathrm{bX}$

Dimana :

$\mathrm{Y}$

a : Konstanta

b : Koefisien regresi

X $\quad$ : Sistem Informasi Sumber Daya Manusia

Tabel 4.7 menunjukkan bahwa model yang digunakan untuk menduga pengaruh tersebut adalah :

\section{$Y=1.212+0.973 X$}

Persamaan tersebut dapat dijelaskan sebagai berikut :

a. Konstanta (a) bernilai 1.212hal ini menjukkan bahwa variabel X (sistem informasi sumber daya manusia) tidak berubah (konstan) maka perencanaan karir karyawan juga akan tetap sebesar 1.212

b. Koefisien regresi $\mathrm{X}$ sebesar 0.973 hal ini menunjukkan bahwa setiap sistem informassi sumber daya manusia 0.973 maka perencanaan karir karyawan juga akan bertambah 0.973 Dengan demikian berdasarkan analisis regresi linier sederhana diatas dapat disimpulkan bahwa sistem informasi sumber daya manusia pada PT. Perkebunan Nusantara III Kebun Aek Nabara Selatan sangat dipengaruhi oleh perencanaan karir karyawan.

\section{Uji validitas dan reabilitas}

\section{a. Uji validitas}

Uji validitas digunakan untuk mengukur sah atau valid tidaknya suatu kuesioner. Hasil penelitian dianggap valid apabila terdapat kesamaan antara data yang terkumpul dengan data yang sesungguhnya terjadi pada objek yang diteliti. pengujian validitas menggunakan rumus product moment dari Pearson yang dilakukan dengan menghitung korelasi antar masing-masing skor item pertanyaan dari tiap variabel dengan total skor variabel tersebut. Jika skor item tersebut berkorelasi positif dengan skor total skor item dan lebih tinggi dari korelasi antar item, menunjukkan kevalidan instrumen tersebut. Untuk penelitian ini, nilai df dapat dihitung sebagai berikut $\mathrm{df}=\mathrm{N}-2$ atau 138$2=136$, dengan tingkat signifikansi sebesar 0,05 maka didapat $r$ tabel sebesar 0,176. Hasil pengujian validitas dapat dilihat pada tabel berikut ini: 
Jurnal Ecobisma Vol 1 No. 12014

Tabel VI.8

Nilai r ritung untuk Variabel Sistem Informasi Sumber Daya Manusia

\begin{tabular}{|l|l|l|l|}
\hline No item & $\mathbf{r}_{\text {hitung }}$ & rabel & keterangan \\
\hline 1 & 0.492 & 0.176 & Valid \\
\hline 2 & 0.366 & 0.176 & Valid \\
\hline 3 & 0.578 & 0.176 & Valid \\
\hline 4 & 0.806 & 0.176 & Valid \\
\hline 5 & 0.835 & 0.176 & Valid \\
\hline 6 & 0.616 & 0.176 & Valid \\
\hline 8 & 0.456 & 0.176 & Valid \\
\hline 9 & 0.505 & 0.176 & Valid \\
\hline 10 & 0.572 & 0.176 & Valid \\
\hline
\end{tabular}

Berdasarkan pada tabel diatas, dapat diketahui bahwa dari 10 item pertanyaan yang terdapat pada angket sistem informasi sumber daya manusia memiliki $r_{\text {hitung }}(0.366-0.842)$ dan $r_{\text {tabel }}$ (0.176) maka dapat dinyatakan bahwa seluruh item dalam variabel sistem informasi sumber daya manusia memiliki item-item yang valid.

\section{Tabel VI.9}

Nilai rhitung untuk Variabel Perencanaan Karir Karyawan

\begin{tabular}{|l|l|l|l|}
\hline No item & rhitung & rtabel & keterangan \\
\hline 1 & 0.533 & 0.176 & Valid \\
\hline 2 & 0.370 & 0.176 & Valid \\
\hline 3 & 0.667 & 0.176 & Valid \\
\hline 4 & 0.838 & 0.176 & Valid \\
\hline 5 & 0.851 & 0.176 & Valid \\
\hline 6 & 0.618 & 0.176 & Valid \\
\hline 7 & 0.442 & 0.176 & Valid \\
\hline 8 & 0.548 & 0.176 & Valid \\
\hline 9 & 0.667 & 0.176 & Valid \\
\hline 10 & 0.815 & 0.176 & Valid \\
\hline
\end{tabular}

Berdasarkan pada tabel diatas, dapat diketahui bahwa dari 10 item pertanyaan yang terdapat pada angket perencanaan karir memiliki $r_{\text {hitung }}(0.370-0.851)$ dan $r_{\text {tabel }}(0.176)$ maka dapat dinyatakan bahwa seluruh item dalam variabel perencanaan karir memiliki item-item yang valid.

\section{b. Uji Reliabilitas}

Menurut Sugiyono (2012: 110) reliabilitas merupakan tingkat kehandalan suatu instrumen penelitian. Instrumen yang reliabel adalah instrumen yang apabila digunakan berulang kali untuk mengukur objek yang sama akan menghasilkan data yang sama. Untuk mengukur reliabilitas digunakan teknik alpha, dimana suatu instrument 
Jurnal Ecobisma Vol 1 No. 12014

dapat dikatakan reliable bila memiliki niai koefisien alpha lebih besar dari $\mathrm{r}_{\text {tabel }}$ sebesar 0,176 atau lebih. Hasil pengujian reliabilitas instrumen penelitian sebagai berikut :

Tabel VI..10

Hasil Uji Reliabiltas Sistem Informasi Sumber Daya Manusia

\begin{tabular}{|l|l|}
\hline Cronbach's Alpha & N of Items \\
\hline .741 & 11 \\
\hline
\end{tabular}

Sumber : Data Diolah (2015)

Berdasarkan Tabel 4.10 diperoleh bahawa nilai cronbach's alpha $(0,741 \geq 0,176)$ maka dapat dikatakan bahwa angket sistem informasi sumber daya manusia reliabel dan memiliki tingkat kepercayaan dengan katagori tinggi untuk dijadikan alat untuk mengukur sistem informasi sumber daya manusia.

Tabel VI..11

Hasil Uji Reliabiltas Perencanaan Karir Karyawan

\begin{tabular}{|l|l|}
\hline Cronbach's Alpha & N of Items \\
\hline .748 & 11 \\
\hline
\end{tabular}

Sumber : Data Diolah (2015)

Berdasarkan Tabel 4.11 diperoleh bahawa nilai cronbach's alpha $(0,748 \geq 0.176)$ maka dapat dikatakan bahwa angket perencanaan karir karyawan reliabel dan memiliki tingkat kepercayaan dengan katagori tinggi untuk dijadikan alat untuk perencanaan karir karyawan.

\section{Pengujian hipotesis}

\section{a. Uji parsial (Uji t)}

Uji parsial (uji t) dilakukan untuk menguji secara parsial (individu) apakah sistem informasi sumber daya manusia berpengaruh terhadap perencanaan karir karyawan, dapat dilihat pada Tabel 4.12 berikut :

Tabel VI.12

Hasil Uji Parsial (Uji t )

coefficients $^{\mathrm{a}}$

\begin{tabular}{|l|l|l|l|l|l|}
\hline Model & \multicolumn{2}{|l|}{$\begin{array}{l}\text { Unstandardized } \\
\text { Coefficints }\end{array}$} & $\begin{array}{l}\text { Standardized } \\
\text { Coefficies }\end{array}$ & $\mathrm{t}$ & Sig. \\
\cline { 2 - 4 } & B & Std. Error & Beta & & \\
\hline
\end{tabular}




\begin{tabular}{|c|c|c|c|c|c|}
\hline \multicolumn{6}{|c|}{ Jurnal Ecobisma Vol 1 No. 12014} \\
\hline (constant) & 1.212 & 1.307 & & .928 & .355 \\
\hline $\begin{array}{l}\text { Sistem Informasi } \\
\text { Sumber Daya } \\
\text { Manusia }\end{array}$ & .973 & .31 & .937 & 31.330 & .000 \\
\hline
\end{tabular}

\section{Sumber : data diolah (2015)}

Dengan membandingkan antara $t_{\text {hitung }}$ dengan $t_{\text {tabel}}$, maka akan dapat disimpulkan bahwa :

Jika $\mathrm{t}_{\text {hitung }} \leq \mathrm{t}_{\text {tabel }}$ maka $\mathrm{H}_{0}$ diterima

Jika $t_{\text {hitung }} \geq \mathrm{t}_{\text {tabel }}$ maka $\mathrm{H}_{0}$ ditolak

Jadi, keputusan hasil analisis uji t variabel independent adalah sistem informasi sumber daya manusia $(X)$ sebesar $31.330 \geq t_{\text {tabel }}$ sebesar 1.977 ini berarti sistem informasi sumber daya manusia berpengaruh secara signifikan terhadap perencanaan karir karyawan .

\section{b. Koefisien determinasi (R2)}

Analisis koefisein determinan digunakan untuk melihat seberapa besar pengaruh variabel sistem informasi sumber daya manusia terhadap perencanaan karir. Hasil pengujian koefisien determinasi dapat dilihat dari Tabel 4.13 sebagai berikut :

Tabel VI.13

\section{Koefisien determinasi}

Model Summary

\begin{tabular}{|l|l|l|l|l|}
\hline Model & $\mathrm{R}$ & $\mathrm{R}$ Square & Adjusted R Square & $\begin{array}{l}\text { Std. Error of the } \\
\text { Estimate }\end{array}$ \\
\hline 1 & $.934^{*}$ & .873 & .872 & 1.144 \\
\hline
\end{tabular}

a. Predictors: (Constant, sistem informasi sumber daya manusia)

Uji $\mathrm{R}^{2}$ ( $\mathrm{R}$ square) dilakukan untuk mengetahui derajat hubungan anara variabel bebas/ independent (X) secara bersama - sama terhadap variabel terikat / dependent (Y). pada hasil diatas dapat dilihat bahwa koefisin determinan $\left(\mathrm{R}^{2}\right)$ adalah sebesar 0.873.nilai sebesar 0.873ini menunjukkan bahwa perencanaan karir karyawan (Y) dapat menjelaskan sistem informasi sumber daya manusia (X) secara bersama - sama sebesar $87.3 \%$ dan sisanya $12.7 \%$ dipengaruhi oleh faktor lain diuar variabel independent.

\section{KESIMPULAN DAN SARAN}

VII. 1. Kesimpulan 
Dari hasil penelitian ini dapat disimpulkan sebagai berikut :

\section{Jurnal Ecobisma Vol 1 No. 12014}

1. Berdasarkan hasil persamaan koefisien regresi linier sederhana diperoleh $Y=1.212+0.973$

Persamaan tersebut dapat dijelaskan sebagai berikut :

a. Konstanta (a) bernilai 1.212 hal ini menjukkan bahwa variabel X (sistem informasi sumber daya manusia) tidak berubah (konstan) maka perencanaan karir karyawan juga akan tetap sebesar 1.212

b. Koefisien regresi $\mathrm{X}$ sebesar 0.973 hal ini menunjukkan bahwa setiap sistem informassi sumber daya manusia 0.973 maka perencanaan karir karyawan juga akan bertambah 0.973

2. Berdasarkan hasil uji $\mathrm{R}^{2}$ ( $\mathrm{R}$ square) menyatakan bahwa sistem informasi sumber daya manusia memliki pengaruh yang positif terhadap perencanaan karir karyawan. Dan hasil uji $\mathrm{t}$ sistem informasi sumber daya manusia berpengaruh secara signifikan terhadap perncanaan karir karyawan.

\section{2. Saran}

Berdasarkan hasil analisis dan kesimpulan penelitian, maka diajukan beberapa saran sebagai berikut :

1. Sebaiknya PT. Perkebunan Nusantara III Kebun Aek Nabara Selatan tetap memperbaharui sistem informasi sumber daya manusia dalam menyimpan, mengolah, memelihara, mendistribusikan dan menyajikan data-data karyawan.

2. Sebaiknya PT. Perkebunan Nusantara III Kebun Aek Nabara Selatan lebih memperhatikan lagi sistem informasi sumber daya manusia sebab ada beberapa karyawan yang merasa belum puas terhadap perencanaan karir yang diberikan.

\section{DAFTAR PUSTAKA}

Arikunto, suharsimi. 2013. Prosedur Penelitian Suatu Pendekatan Praktik. Edisi Revisi. Jakarta : Rineka Cipta.

Dikatara. 2011. sistem informasi sumber daya manusia. https://dikatara.wordpress.com/2011/11/30/sistem-informasi-sumber-daya-manusia, tanggal akses 20/05/2015. 


\section{Jurnal Ecobisma Vol 1 No. 12014}

Handoko, hani. 2014. Cetakan keduapuluh satu. Manajemen Personalia dan Sumber Daya Manusia. Yogyakarta. BPFE.

Hasibuan, Malayu. 2013. cetakan ketujuh belas. Manajemen Sumber Daya. Jakarta : bumi aksara. junaidi. 2010. Tabel $r$. http://junaidichaniago.wordpress.com. tanggal akses 19/11/2015. junaidi. 2010. Tabel t. http://junaidichaniago.wordpress.com. tanggal akses 19/11/2015.

Konsistensi. 2013. Teori sampel dan sampling penelitian. www.Konsistensi.com/2013/04/teorisampel-dan-sampling-penelitian-html, tanggal akses 22/05/2015.

luthfiakumala. Blogspot.com/2012/10/perencanaan-dan-pengembangan-karir. html, tanggal akses 20/06/2015.

Machfoedz, mahmud. 2007. Pengantar Bisnis Modern. Yogyakarta : Andi. manusia. Jakarta: PT. Bumi Aksara.

Samsudin, sadili. 2010. Cetakan ke-3. Manajemen Sumber Daya Manusia. Bandung : CV. PUSTAKA SETIA.

Siagian, sondang. 2008. Cetakan kelima belas. Manajemen Sumber daya Manusia. Jakarta. : PT. Bumi Aksara..

Simamora, henry. 2004. Manajemen sumber daya manusia. Yogyakarta : YKPN.

Sugiyono. 2011. Cetakan ke-19. Statistik untuk Penelitian. Bandung : Alfabeta.

Sugiyono. 2012. Cetakan ke-16. Metode Penelitian Bisnis. Bandung : Alfabeta.

Sunyoto, danang. 2015. Cetakan pertama. Penelitian Sumber daya manusia. Yogyakarta: CAPS.

Sutrisno, edy. 2012. Cetakan ke-4. Manajemen Sumber Daya Manusia. Jakarta : Kencana Prenada Media Group

Yani, M. 2012. Manajemen Sumber Daya Manusia. Jakarta : Mitra Wacana Media. 